\title{
Knowledge Exchange fortsætter og udgiver ny rapport om preprints
}

\author{
Danmark er fortsat med i Knowledge Exchange \\ (KE) samarbejdet, siden juni 2019 med Styrelsen \\ for Forskning og Uddannelse i stedet for DEFF som \\ dansk partnerorganisation.
}

KE offentliggør mange resultater fra igangværende projekter lige nu, og har senest publiceret en ny rapport om preprints.

Formålet er blandt andet, at ansatte i forskningsbibliotekssektoren skal have glæde af resultater og viden fra dette samarbejde.

Den seneste rapport fra KE

"Accelerating scholarly communication - The transformative role of preprints", er en analyse af, hvilken rolle preprints spiller I den videnskabelige publiceringproces. Preprints defineres som versioner af forskningsartikler typisk før peer-review og inden den endelige publicering i et tidsskrift.

Ud over et omfattende literature review, har KE foretaget interviews med 38 forskellige interessenter på tværs af 6 europæiske lande, deriblandt forskere, forskningsinstitutioner, fundere og preprint servere/service udbydere for blandt andet at undersøge følgende spørgsmål:

Hvad er de væsentligste fordele og ulemper ved preprints? Hvilken værdi tillægges preprints og hvilken rolle spiller twitter i distributionen af preprints? Hvem vil være ansvarlig for at distribuere preprints i fremtiden? Og vil det ændre traditionelle tidsskrifters publicering?

\section{Læs mere her \\ Den endelige rapport: $\underline{\text { http://bit.ly/acceleratingscholcomms }}$ \\ Et resumé: http://bit.ly/execacceleratingscholcomms \\ KE Website: http://www.knowledge-exchange.info/event/preprints}

I er meget velkomne til at kontakte Anna Mette Morthorst, Danmarks repræsentant i Knowledge exchange gruppen, hvis I vil vide mere om rapporten eller KE’s (øvrige) aktiviteter.

Anna Mette Morthorst,anmo@ufm.dk

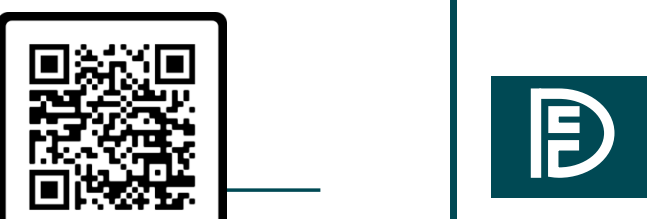

SCAN ME 